\title{
Profit Shares as Virtual Equity: Short-Run Isomorphism of Share \& Wage Systems
}

\author{
Vikram Kumar $^{1}$ \\ ${ }^{1}$ Department of Economics, Davidson College, Davidson, North Carolina, USA \\ Correspondence: Vikram Kumar, Department of Economics, Davidson College, Davidson, North Carolina, USA. \\ E-mail: vikumar@davidson.edu
}

Received: April 28, 2019

Accepted: May 17, 2019

Online Published: May 28, 2019

doi:10.5539/ijef.v11n7p45

URL: https://doi.org/10.5539/ijef.v11n7p45

\begin{abstract}
An important argument in favor of public policy to promote profit-sharing arrangements - and one that distinguishes it from the canonical wage system - is that it creates a macroeconomic externality in the form of short-run excess demand for labor. In this paper we provide insights new in the literature to show that the two systems are isomorphic. We consider the most plausible basis for the distribution of the profits between labor and capital to be one that is conceptually consistent with the functional role of labor as a residual claimant. We postulate a sharing rule that is based on the recognition that in a profit-sharing system a portion of labor's contribution is a form of equity - virtual equity - analogous to shareholder equity. With this interpretation, if the share parameter of worker pay is endogenously determined then we show that, eschewing any independent productivity effects, a profit-sharing system is not consistent with said macroeconomic externality. This analysis provides a framework to assess recent public policy initiatives and legislative proposals on both sides of the Atlantic, arguing that their advocation can be based on distributive but not efficiency grounds.
\end{abstract}

Keywords: profit-sharing, virtual equity, distribution of profits, sharing rule, public policy

\section{Introduction}

Interest in the properties and effects of profit-sharing systems has a long history. It is well known that both Adam Smith (1937, p. 367) and Marshall (1964, pp. 535-536) raised concerns about the inefficiency of sharecropping, Mill writes approvingly of a M. Leclaire's profit-sharing system in his house painting business in Paris (1899, pp. 277-280), and Schumpeter (1954, p. 467) suggests that von Thunen's idea of the 'natural wage' may have useful applications in the context of profit-sharing.

The resurgence of distributional issues in the contemporary political-economic discourse points to renewed interest in examining alternative relationships between labor and capital. For instance, the recently introduced Accountable Capitalism Act envisages broad institutional changes including requiring corporations to ensure that "Not less than $2 / 5$ of the directors of a United States corporation shall be elected by the employees of the United States corporation" (S.3348, 2018, p. 17). Such changes, if forthcoming, would invariably have implications for the structure of worker pay also; the shadow Chancellor of the U.K. Labor Party has announced the party's intention of setting up Inclusive Ownership Funds requiring transfer of equity to workers if the party is elected to power (Partington, 2018).

Numerous firm-level effects of profit-sharing arrangements - where the worker's pay is composed partly of a fixed base wage and the remainder as a share of the firm's profit per worker - have been studied as discussed below. The macroeconomic effects of a profit-sharing system, which have received less attention, have focused on the putatively attractive notion that such an economy will be in a chronic state of excess demand for labor even in the short-run, and therefore it will be less susceptible to cyclical fluctuations (see, for instance, Weitzman, 1984). This positive externality of profit-sharing then leads to the corollary that government should provide subsidy support to firms to adopt profit-sharing arrangements for efficiency reasons.

In this paper we argue that there is no difference between the macroeconomic effects of the share and traditional wage systems and that the two are in fact isomorphic. We develop a model to show that the claim of short-run excess demand for labor is an artifact that rests on two weak foundations: firstly, the assumption that the firm takes as exogenously given the share parameter applied to its per-worker profit in determining the worker's 
total remuneration, and secondly, that the labor market disequilibrium is measured without reference to the opportunity cost of labor which is determined by the going wage in the traditional wage sector.

We extend the literature to provide new insights by postulating that the most plausible and methodologically correct basis for the distribution of the profits between labor and capital is one that is conceptually consistent with the functional role of labor as a residual claimant, one that is identical to the role of the capitalist. By articulating a rule based on this principle we show that there is no difference between the canonical wage and share systems; eschewing any independent productivity-enhancing effects, the share system is a cosmetic construct with no separate economic effects.

The next section provides a review of the literature and models a profit-sharing system with an exogenous share parameter to argue why the short-run excess demand proposition does not go through. In section 3 we re-interpret labor's role in firm as the provision of virtual equity proximately equivalent to the role of traditional shareholder equity, propose a profit-sharing rule based on that interpretation, and consider its macroeconomic implications. Public policy implications are considered in section 4 and concluding comments are provided in section 5 .

\section{A Profit-Sharing System with Exogenous Share Parameter}

\subsection{Review of the Literature}

Profit-sharing is often administered in industry on the premise that imbuing labor with a sense of ownership of the enterprise and attaching their personal fortunes to that of the firm will enhance labor productivity. Such views also often assume of some amount of worker participation in decision-making and limited managerial control in the sense of codetermination as a necessary part of profit-sharing systems. The literature on payment arrangements such as performance related pay naturally emphasizes firm-level effects such as its impact on the quality of candidates selecting into the firm from heterogeneous labor pools and their productivity effects when effort is unobservable (Lazear, 1986). Broadly, commission and bonus payments promote labor productivity effects (Blasi, Kruse, \& Freeman, 2018), and profit sharing and stock options are often adopted to impact labor selection (Oyer \& Shaefer, 2005).

Distinct from these considerations, a separate strand of research on profit-sharing that is closely associated with Weitzman $(1985,1984,1983)$ inquires into the macroeconomic properties of an economy populated by profit-sharing firms. This focus on the macroeconomics of the profit-sharing system stemmed partly from the sub-par labor market performance of major European economies. Implicit in this line of research has been the hope that structural changes in the way worker compensation is determined will enhance employment and insulate economies from macroeconomic instability by making worker pay more flexible and responsive to the state of the market. More recently doubt has been cast on this view; for instance, as noted by Ninomiya and Takami (2018), the early belief that the Japanese economic miracle was based on corporate governance centered around the idea of profit-sharing seems to be belied by a prolonged recession and secular stagnation that is incongruent with the putative stabilizing properties of a share system.

By "linking compensation with profits, Weitzman suggested that firms would not have to lay as many people off and real wages would adjust to cyclical factors" (Makridis, \& Gittleman, 2019, p. 5). The basic idea behind this compensation scheme is that if total pay were composed of a base wage and a share of the firm's profit per worker then worker remuneration would become pro-cyclical and would therefore be stabilizing. It has been argued that in an economy with such a profit-sharing arrangement the firm would be in a perpetual state of excess demand for labor and the share system will provide full employment even in the short-run. For instance, Weitzman (1984, p. 97) notes that profit-sharing "automatically stabilizes the economy at full employment, even before the long-run tendencies have had the chance to assert their dominance" (italics added) and that this system "has the direct 'strong force' of positive excess demand for labor."

Using a simple model of profit-sharing we show below that the short-run excess demand for labor proposition is erroneous, this conclusion resulting from (a) not taking into account the opportunity cost of labor in the profit-sharing firms as determined by the traditional wage firm, and (b) assuming that the share of per-worker profit is exogenous to the firm and does not take account of the altered functional role of labor to the extent that it becomes a residual claimant.

\subsection{Profit-Sharing with Exogenous Share Parameter}

The compensation of a worker in a firm in the profits-sharing sector is the sum of a base wage $w$, and a share $s$ of the profit (before distribution between labor and capital) $\pi$ per worker $l$. The compensation in the traditional wage sector is the going wage $W$, and $w<W$. Assume that a competitive firm hires labor to 
produce output $q=f(l)$ where $f^{\prime}(l)>0, f^{\prime \prime}(l)<0$. The parameters of the share system $(w, s)$ are arbitrary, set by custom or norm. Thus, the firm maximizes its own share of the profit $\Gamma_{S}=(1-s) \pi$ where:

$$
\Gamma_{S}=(1-s)[f(l)-w l]
$$

With $s$ given exogenously this exercise amounts to maximizing $\pi$ itself, yielding the standard first-order condition:

$$
f^{\prime}(l)=w
$$

The resulting demand for labor is:

$$
l^{d}=f^{\prime-1}(w)
$$

where $\partial l^{d} / \partial w<0$. Competition for labor ensures that the worker receives identical remunerations under both the traditional wage and profit-sharing systems, i.e.:

$$
W=w+s \frac{\pi(l)}{l}
$$

The supply of labor is based on the total earnings of labor:

$$
l^{s}=g(W)
$$

In the traditional wage system $(w=W)$, the wage would adjust to determine employment $l^{*}$ such that:

$$
f^{\prime-1}(W)=l^{*}=g(W)
$$

However, it is argued that share systems generate greater demand pressure on the labor market. Since $w<W$ and because $\partial l^{d} / \partial w<0$ it is suggested that that under a profit-sharing system the labor market is in a state of chronic excess demand:

$$
f^{\prime-1}(w)-g(W)>0
$$

The notion of 'excess demand' for labor in this telling is contrary to the canonical use of the term in characterizing the state of the labor market. This interpretation is unusual because any disequilibrium in the labor market is meaningfully measured only at the value of the opportunity cost of labor. For instance, under a binding minimum wage, the excess supply of labor is measured at the level of the minimum wage since that wage is effectively labor's opportunity cost of labor. The excess demand for labor in (7) arises because labor demand is measured at the base wage $w$ which is below labor's opportunity cost $W$. The suggestion that a firm has an excess demand for labor below the opportunity wage is a truism; it applies to all firms, not simply profit-sharing ones.

The profit-sharing firm is not constrained in the labor market since it can hire any amount of labor it wants to at the opportunity wage of labor. As noted by Blanchflower and Oswald (1987, p. 5) "Weitzman's claims for the attractiveness of the share economy rest upon the notion of an equilibrium in which there is continual excess demand for labor. This is not easy to take seriously. Competition among firms to hire limited quantities of labor would naturally and gradually force up the wage level. The familiar wage system...might be expected to reappear." Indeed, the idea that competitive labor markets will continually be in a state of excess demand, without a specific description of the conditions under which disequilibrium can persist does not seem persuasive. In any event, the upshot of this paper is that if profit-sharing is governed by the principle that recognizes the functional equivalence of capital and labor articulated below then there will be no such excess demand in the labor market.

How, then, is labor's share of profit determined? On this critical question Weitzman is silent and "neglects the determination of the relative weights of the fixed and the variable components of the share contract...yet he takes for granted, for no good reason, that the fixed element of pay can be compressed down to whatever is the full employment marginal revenue product of labor" (Nuti, 1991). We show below that if the profit share parameter is endogenously determined by the principle that inputs that are functionally symmetric should be compensated symmetrically, then no such disequilibrium will characterize the labor market and the profit-sharing outcome will be isomorphic to the traditional wage one.

\section{Profit Shares as Virtual Equity}

If the profit share parameter $s$ is not arbitrarily given, then the question is: what is the conceptually proper basis for determining how the profits of the firm should be distributed between labor and capital, i.e., how should $s$ be determined? The answer rests upon a recognition of the functional role of the portion of labor services whose reward is drawn from the residual. As a residual claimant labor is functionally analogous to canonical 
shareholder equity. Thus, in terms of equation (4), if each worker were to claim only an amount $w$ of the total compensation $W$ as the (base) wage, then the rest, $W-w$, in principle should be treated symmetrically with returns to shareholder or outside equity. To set the concept we refer to the profit-based portion of worker compensation, $s \pi(l) l^{-1}$, as the flow service of virtual equity in the production process.

The nomenclature virtual equity distinguishes the physical nature of this portion of labor's contribution from that of the outside equity. It emphasizes the fact that for a given physical factor-mix the functional mix of inputs changes with the profit-share component of total pay. Early literature on this subject has hinted at this conceptual framework, though there was no effort in applying it towards determining the share parameter. For instance, Wadhwani (1990, p. 4) notes that "a genuine profit-sharing scheme effectively reduces the true debt-equity ratio, with a part of workers' claims on the firm becoming more akin to equity." Meade (1986) also recognizes this principle in arguing for his Discriminating Labor Capital Partnership but leaves unresolved its implications for the division of profits between workers and capitalists.

We postulate that recognition of this change in the functional role of labor is essential for designing a methodological sound basis for the division of the firm's profit between virtual and outside equities. The outside equity of shareholders is a stock whereas the virtual equity component of labor services is measured as a flow. While we do not endogenize risk in the following analysis, it also bears notice that the difference in virtual and outside equity also includes differences in the nature of risk borne by virtual and outside equities.

The value of the stock of outside equity from which outside equity's (capital) services flow is subject to variability, in the sense of capital gains and losses, in quite a different way than is the value of the underlying stock of labor from whence labor services flow. More precisely, the liability of capital owners is limited to the entire stock of outside equity, whereas the liability of labor is limited not to the value of the underlying stock of labor but to the value of the fraction of the flow services of labor that are provided in a given period of time. For conceptual consistency, therefore, any given amount of the residual should first compensate outside equity owners for the difference in risk of changes in the value of their stock. Only the remainder of the profits should be distributed between labor and capital. We assume below that outside equity is not subject to capital gains and losses so that outside and virtual equities are conceptually homogeneous.

Similarly, different divisions of the opportunity pay $W$ between the base wage $w$ and the share component in an uncertain world imply different levels of risk for the same expected pay-off. In an uncertain world a risk premium would be required to motivate labor to substitute in effect a lottery under profit-sharing with a lottery under the traditional wage system with a fixed wage $W$ conditional on the state of employment. The literature on performance related pay mentioned above substantially treats this issue by considering productivity enhancing effects of share contracts that provide the firms the necessary additional output to fund the risk premium. Our focus, though, is on re-examining macroeconomic properties of the share system vis-à-vis the Weitzman-type system which assumes, as we do herein, that labor is risk neutral, but with the key difference that we treat the share parameter as endogenously determined.

For any given base wage, then, let the income from virtual equity in the total pay of workers be defined as:

$$
a(w)=\frac{W-w}{W}
$$

We can then denote the flow services of virtual equity $E_{V}$ and outside equity $E_{O}$ as follows:

$$
\begin{aligned}
& E_{V}=a(w) W l \\
& E_{O}=i Y
\end{aligned}
$$

In (9) $Y$ is the stock of shareholder or outside equity and $i$ is a stock-flow conversion factor or the appropriate rate at which the future stream of profits is discounted. The total flow services of total functional equity $E_{F}$ is given by:

$$
E_{F}=E_{V}+E_{O}
$$

The interpretation of labor's share of profits as the flow services of virtual equity suggests that the distribution of the firm's profit between labor and capital should be in accordance with the following profit-sharing rule: For any given base wage $w$, the share $s$ of the firm's profit awarded to virtual equity should be equal to the share of virtual equity in the firm's total functional equity:

$$
s=\frac{E_{V}}{E_{V}+E_{O}}
$$


Since the rate of return on outside equity $i=(1-s) \pi Y^{-1}$, this substitution in (9) together with (11) yields:

$$
s(l ; w)=\frac{a(w) W}{\pi(l) / l}
$$

Equation (12) makes clear that from the firm's perspective, the share parameter $s$ is a function of labor for any given base wage $w$, and further that of the total profit per worker, the share accruing to the worker is directly proportional to the contribution to virtual equity service $a$ that she provides.

The firm's objective now is to choose $l$ to maximize its own share of profit subject to (12):

$$
\Gamma_{S}=(1-s(l ; w))[f(l)-w l]
$$

In the maximand in (13) the share parameter $s$ depends on the firm's choice of labor, which differs from the maximand in (1) in that $s$ is exogenous to the firm's decision process. The first-order necessary condition now is (Note1 1):

$$
f^{\prime}(l)=w+s \frac{\pi(l)}{l}
$$

But the right-hand side of (14) is the wage prevailing in the traditional wage system $W$ as given in (4), which is the true opportunity cost of labor. So, in contrast to the first order condition in (2) it is readily seen that the firm's hiring decisions under both the canonical wage and share systems are identical even in the short-run. Indeed, the labor demand under both systems is $l^{d}=f^{-1}(W)$ and a methodologically consistent rule for apportioning the firm's profit between labor and capital rejects the case for a short-run equilibrium with chronic excess demand for labor.

Equation (12) also implies that in equilibrium (Note1 2):

$$
\frac{\partial s(l)}{\partial l}=\frac{s(1-s)}{l}>0
$$

Hence to the firm the true cost of hiring an extra worker is not merely the base wage $w$. The addition of an extra worker in the share system also increases the share parameter $s$, so that in calculating the full cost of an extra worker the firm must also include the reduction in its existing share of profit as a consequence. It is this effect that the Weitzman model, with its assumption of exogenously determined share parameter fails to capture. So its employment implication is misplaced to the extent that share contract is not exogenously specified but rendered in accordance with the profit-sharing rule stated above.

It has been shown that in a share system where wage is determined according to the efficiency wage model, a firm's labor demand is no different under either the share system or the wage system. For instance, Wadhwani (1987, p. 426) notes that under the efficiency wage class of theories "the wage and share systems will ... be isomorphic in the short-run...(T) his means that we can forget about the short-run excess demand of labor proposition...The form in which you pay workers becomes irrelevant." We have shown that the same result holds without invoking the efficiency wage framework if the profit-sharing rule is based on the share of virtual equity in the total functional equity of the firm, an interpretation that is new in the literature.

\section{Public Policy Implications}

The principle of allocating profits to labor in proportion to its contribution to the firm's total functional equity entails outcomes consistent with firm and worker incentives that lead to isomorphic profit-sharing and traditional wage systems. The firm does not hire up to $f^{\prime-1}(w)$ not because of any presumed labor constraint as per (7) but, due to the curvature of production, doing so while also satisfying the pay constraint would reduce its own share of profit below the level it would receive under the traditional wage system. Given the pay constraint in (4), the second-order Taylor's series expansion of the firm's profit $\Gamma_{S}$ in (1) around $l^{*}$ yields (Note1 3):

$$
\Gamma_{S} \approx \Gamma_{W}+\frac{1}{2} f^{\prime \prime}\left(l^{*}\right)\left[f^{\prime-1}(w)-l^{*}\right]^{2}
$$

In (16) $\Gamma_{W}$ is the profit of the firm under the traditional wage system. Since $f^{\prime \prime}(l)<0$ (16) implies that $\Gamma_{S}<\Gamma_{W}$. Therefore the firm will never have a private preference for profit-sharing unless it is cosmetic. 


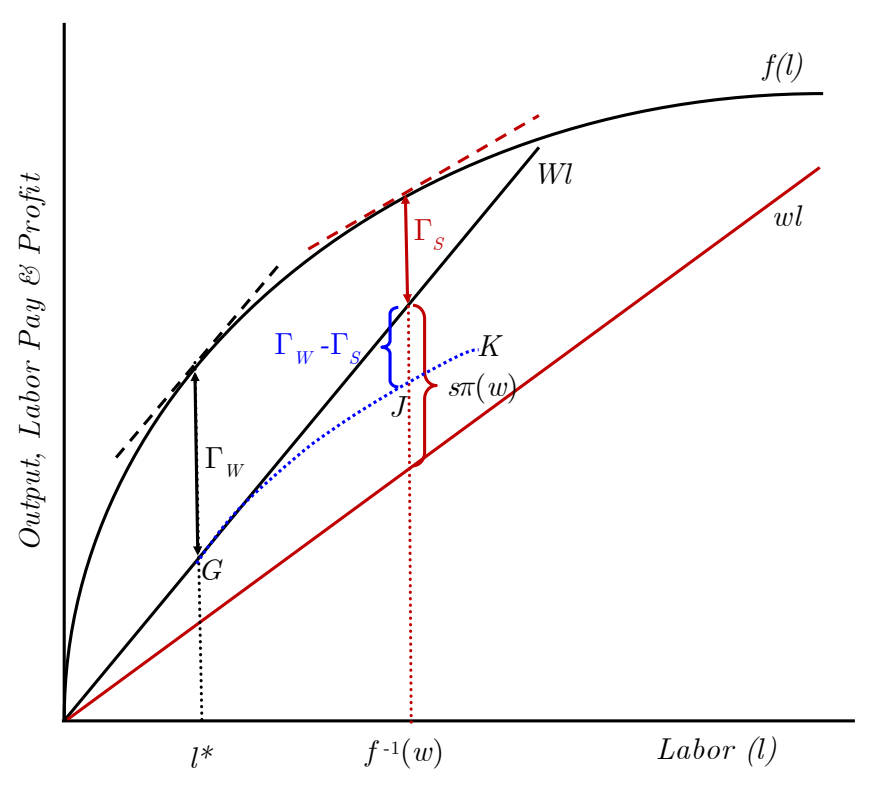

Figure 1. Distribution of the firm's output under profit-sharing with exogenous \& endogenous share parameter

Figure 1 illustrates the distribution of the firm's product between labor and capital under traditional wage and profit-sharing arrangements. If worker pay in the latter must compete with the opportunity wage $W$ in former, then even with the base wage $w$ the total labor pay including labor's share of the profit $s \pi(w)$ must be $W f^{\prime-1}(w)$. Starting at $l^{*}$, the firm's output $f(l)$ increases at a smaller rate than the total labor pay $W l$ resulting in profit reduction for outside equity holders in the amount $\left(\Gamma_{W}-\Gamma_{S}\right)$. For the firm to increase employment and retain the profit of outside equity unchanged at $\Gamma_{W}$, the total labor compensation including both the base and share components would need to grow along the dashed arc $G J K$ whose curvature parallels production $f(l)$. In practice this could be accomplished by a tiered base wage with $\left(f^{\prime-1}(w)-l^{*}\right)$ workers earning less than others (Note1 4$)$ in a two-tiered system $\left(f^{\prime-1}(w)-l^{*}\right)$ workers would earn a base wage given by the slope of a ray through points $G$ and $J$ which would be less than $W$. But this tiered pay system would only be possible if there were entry barriers in the labor market to sustain non-competing groups. Howsoever achieved, it would require a lower average pay per worker to convince firms to adopt profit-sharing plans.

Though there is no private incentive for a competitive firm operating in a competitive labor market to enter into a profit-sharing arrangement, it could be induced to do so by means of a tax rebate in the amount $\left(\Gamma_{W}-\Gamma_{S}\right)$ to offset the reduction in its share of profit. Advocation of tax incentives to promote profit-sharing has been argued on the basis of its putative positive external effects on the economy in the form of short-run excess demand for labor that keeps recessions at bay. Based on our analysis, the labor demand effects under the two systems are isomorphic, so tax incentives would only lead to a cosmetic profit-sharing system but one which simulates the effects of other employment-enhancement policies such as the provision of wage subsidies or other types of employment incentives such as payroll tax reductions.

Under the U.K. Labor Party's Inclusive Ownership Funds proposal, for instance, firms "would transfer at least 1\% of ownership into the fund each year, up to a maximum $10 \%$," and these shares would be collectively controlled by the workers, who would have the same voting rights as other investors." (Partington, 2018). Public policy proposals to expand profit-sharing arrangements such as this, and the Accountable Capitalism Act (S.3348, 2018) in the U.S., lacking beneficial external effects for reasons given above, would be more persuasively promoted on distributive rather than on efficiency grounds and include provisions for codeterminative firm governance along the German model (Mertens \& Schanze, 1979).

\section{Concluding Comments}

There has been renewed interest in labor-capital relations on both sides of the Atlantic as evidenced by pending legislation in the US Senate and the intended reform program of the British Labor Party. In this context this paper has inquired into the macroeconomic implications of a profit-sharing system by highlighting the equivalence of shareholder equity and the virtual equity of labor from which the shared-profit component of pay is derived. This interpretation of labor's role in the firm's enterprise warrants a re-examination of the 
determination of the share parameter of the pay contract and how it impacts certain compelling macroeconomic properties of a profit-sharing system.

This paper offers insights new in the literature in arguing that there is no meaningful macroeconomic distinction between the traditional wage system and a profit-sharing system - that the two systems are isomorphic. We argue that the methodologically correct basis for the distribution of the profits between labor and capital, one that is conceptually consistent with the functional role of labor as a residual claimant, gives to labor a share of the firm's profit equal to the share of labor's contribution of virtual equity in the firm's total functional equity. We argue that if this principle guides the allocation of the firm's profit between labor and capital then there is no difference between the canonical wage and share systems. Therefore, profit-sharing firms do not provide the positive macroeconomic externality that is claimed to arise from such firms being in a chronic state of short-run excess demand for labor.

The corollary follows that without such externality, public policy aimed at promoting profit-sharing arrangements through tax incentive programs are qualitatively no different from other policies which would lead to an increased demand for labor such as payroll-tax reductions or wage subsidies. Such policies would result in cosmetic profit-sharing schemes that work no differently than canonical wage arrangements. Lacking external social benefits, the case for profit-sharing is more persuasively made on distributional rather than efficiency grounds.

The results of our analysis of the macroeconomic effects of profit-sharing do not consider the important firm-level effects of profit-sharing on worker productivity either through worker participation in decision-making and limited codeterminative managerial control or by it impact on worker selection from heterogeneous labor pools when effort is unobservable. Taking account of these effects are promising lines of further inquiry in assessing the macroeconomics of profit-sharing.

\section{References}

Accountable Capitalism Act, S.3348, $115^{\text {th }}$ Congress. (2018).

Blanchflower, D. G., \& Oswald, A. J. (1987). Profit Sharing: Can it Work. Oxford Economic Papers, 39, 1-19. https://doi.org/10.1093/oxfordjournals.oep.a041771

Blasi, J., Kruse, D., \& Freeman, R. B. (2018). Broad-based employee stock ownership and profit sharing: History, evidence, and policy implications. Journal of Participation and Employee Ownership, 1(1), 38-60. https://doi.org/10.1108/JPEO-02-2018-0001

Lazear, E. P. (1986). Salaries and piece rates. Journal of Business, 90, 405-431. https://doi.org/10.1086/296345

Makridis, C., \& Gittleman, M. (2019). On the Cyclicality of Real Wages and Employment: New Evidence and Stylized Facts from Performance Pay and Fixed Wage Jobs. https://doi.org/10.2139/ssrn.3017034

Marshall, A. (1964). Principles of Economics (8th ed.). London: Macmillan.

Meade, J. (1986). Alternative Systems of Business Organisations and Worker' Remuneration. London: George Allen and Unwin.

Mertens, H. J., \& Schanze, E. (1979). The German Codetermination Act of 1976. Journal of Comparative Corporate Law and Securities Regulation, 2, 75-88.

Mill, J. S. (1899). Principles of Political Economy (Vol. 2). New York: The Colonial Press.

Ninomiya, K., \& Takami, H. (2018). Profit sharing, labour share and financial structure. Evolutionary and Institutional Economics Review, 15(1), 89-111. https://doi.org/10.1007/s40844-017-0090-5

Nuti, D. M. (1987). Profit - Sharing and Employment: Claims and Overclaims. Industrial Relations, 26, 18-29. https://doi.org/10.1111/j.1468-232X.1987.tb00691.x

Nuti, D. M. (1991). Codetermination and Profit-sharing. In J. Eatwell, M. Milgate, \& P. Newman (Eds.), The World of Economics. The New Palgrave. London: Palgrave Macmillan. https://doi.org/10.1007/978-1-349-21315-3_10

Oyer, P., \& Schaefer, S. (2005). Why do some firms give stock options to all employees? An empirical examination of alternative theories. Journal of Financial Economics, 76, 99-133. https://doi.org/10.1016/j.jfineco.2004.03.004

Partington, R. (2018, September 24). How would Labour plan to give workers $10 \%$ stake in big firms work? Retrieved 
http://www.theguardian.com/business/2018/sep/24/how-would-labour-plan-to-give-workers-10-stake-in-big -firms-work

Schumpeter, J. A. (1954). History of Economic Analysis. New York: Oxford University Press.

Smith, A. (1937). The Wealth of Nations. New York: Modern Library.

Wadhwani, S. B. (1987). Profit-Sharing and Meade's Discriminating Labor-Capital Partnerships: A Review Article. Oxford Economic Papers, 39(3), 421-442. https://doi.org/10.1093/oxfordjournals.oep.a041797

Wadhwani, S. B., \& Wall, M. (1990). The Effects of Profit Sharing on Employment, Wages, Stock Returns, and Productivity: Evidence from UK Micro-data. Economic Journal, 100(1), 1-17. https://doi.org/10.2307/2233593

Weitzman, M. (1983). Some Macroeconomic Implications of Alternative Compensation Systems. Economic Journal, 93(4), 763-783. https://doi.org/10.2307/2232745

Weitzman, M. (1984). The Share Economy. Cambridge, Mass.: Harvard University Press.

Weitzman, M. (1985). The Simple Macroeconomics of Profit-Sharing. American Economic Review, 75(5), 937-953.

\section{Notes}

Note 1. See Appendix 1 for derivation of equation (14).

Note 2. See Appendix 2 for derivation of equation (15).

Note 3. Equation (16) is derived in Appendix 3.

Note 4. This observation is consistent with Nuti (1987, p. 20) that "profit-sharing will not be introduced by firms unless total pay per worker is lower than the alternative fixed wage, to compensate for the (predicted) lower profits and profit share. A lower pay per worker would sacrifice employed workers in favor of those unemployed who would benefit from the employment generated by profit-sharing."

\section{Appendix 1}

\section{Derivation of Equation (14)}

Noting that the profit before distribution to labor is $\pi(l)=f(l)-w(l)$, the first order condition for maximizing (13) by choice of $l$, subject to (12) is:

$$
\frac{\partial \Gamma_{s}}{\partial l}=(1-s)\left[f^{\prime}(l)-w\right]-\pi \frac{\partial s}{\partial l}=0
$$

In (1.1):

$$
\frac{\partial s}{\partial l}=\frac{a(w) W}{\pi}-\frac{a(w) W l}{\pi^{2}}\left[f^{\prime}(l)-w\right]
$$

Since $a(w) W \pi^{-1}=s l^{-1}$ by (12), substitution in (1.2), upon rearrangement, yields:

$$
\frac{\partial s}{\partial l}=\frac{s}{l}\left[\frac{\pi-\left[f^{\prime}(l)-w\right] l}{\pi}\right]
$$

Now, from (8) $w=(1-a) W$. Substituting this expression in (1.3) and collecting terms yields:

$$
\frac{\partial s}{\partial l}=\frac{s}{l}\left[\frac{\pi-a(w) W l}{\pi}+\frac{W-f^{\prime}(l) l}{\pi}\right]
$$

Because by (12) the first term in brackets equals $(1-s)$, (1.4) can be rewritten as:

$$
\frac{\partial s}{\partial l}=\frac{s(1-s)}{l}+\frac{s\left[W-f^{\prime}(l)\right]}{\pi}
$$

Upon substituting the RHS of (1.5) in (1.1) we obtain the necessary first order condition as:

$$
\frac{\partial \Gamma_{S}}{\partial l}=(1-s)\left[f^{\prime}(l)-w\right]-\frac{(1-s) s \pi}{l}-s\left[W-f^{\prime}(l)\right]=0
$$


Upon rearrangement (1.6) reduces to:

$$
f^{\prime}(l)-(1-s)\left[w+\frac{s \pi}{l}\right]-s W=0
$$

Since the term in brackets in (1.7) by equation (4) equals $W$, we obtain:

$$
f^{\prime}(l)=w+s \frac{\pi(l)}{l}
$$

which is equation (14) in the text.

\section{Appendix 2}

\section{Derivation of Equation (15)}

Equations (4) and (14) imply that:

$$
f^{\prime}(l)=W
$$

Upon substituting (2.1) in (1.5) yields:

$$
\frac{\partial s(l)}{\partial l}=\frac{s(1-s)}{l}
$$

(2.2) is equation (15) in the text.

\section{Appendix 3}

\section{Derivation of Equation (16)}

Denote employment under profit-sharing implied by (1) as $l_{w}=f^{\prime-1}(w)$. Then given (4), $\Gamma_{S}=f\left(l_{w}\right)-W l_{w}$. Now, note that under the canonical wage system the firm's profit is $\Gamma_{W}=f\left(l^{*}\right)-W l^{*}$, and employment is $l^{*}=f^{\prime-1}(W)$. The Taylor's expansion of $\Gamma_{S}$ around $l^{*}$ is:

$$
\Gamma_{S}=\left[f\left(l^{*}\right)-W l^{*}\right]+\left[f^{\prime}\left(l^{*}\right)-W\right]\left(l_{w}-l^{*}\right)+\frac{1}{2} f^{\prime \prime}\left(l^{*}\right)\left[l_{w}-l^{*}\right]^{2}
$$

But under the wage system, profit maximization requires $f^{\prime}\left(l^{*}\right)-W=0$. Therefore the middle term of (3.1) equals zero, yielding equation (16).

\section{Copyrights}

Copyright for this article is retained by the author(s), with first publication rights granted to the journal.

This is an open-access article distributed under the terms and conditions of the Creative Commons Attribution license (http://creativecommons.org/licenses/by/4.0/). 